\title{
Road to Peace Education: Peace and Violence from the Viewpoint of Children
}

\author{
Fatih Y1lmaz ${ }^{1}$ \\ ${ }^{1}$ Faculty of Education, Dicle University, Diyarbakır, Turkey \\ Correspondence: Fatih Yılmaz, Faculty of Education, Dicle University, Diyarbakır, Turkey. Tel: 90-412-248-8399. \\ E-mail: fatih.yilmaz@dicle.edu.tr
}

Received: March 30, 2018

Accepted: May 8, $2018 \quad$ Online Published: July 28, 2018

doi:10.5539/ies.v11n8p141

URL: https://doi.org/10.5539/ies.v11n8p141

\begin{abstract}
It is important to adopt the concept of peace as a culture when human rights, democracy, coexistence and diversity are respected at the social level. Particularly at an early age, introducing this concept to individuals can prevent violent cultures from finding social or individual support. In this sense, individuals are expected to disseminate peace through education and to exclude violence. In this research, it was tried to show how primary school students perceive the concepts of peace and violence in their daily lives. It has been tried to determine how pupils describe these concepts in their pictorial image, literary and verbal expressions. The research was designed as qualitative research from qualitative research approaches. 68 primary school students participated in the research. Students have identified four main themes on the peace issue: "universal / inter-communal peace, inter-group / social peace, inter-personal peace and individual peace." Twenty-five sub-themes related to these 4 main themes have been created. As for violence, four main themes have emerged: "socio-cultural violence, direct violence, group violence and ecological violence". Sixteen sub-themes have been expressed, depending on these four main themes. It has been found out that in the general sense, they perceive the concept of peace mostly in a personal-individual sense and they directly perceive the concept of violence as socio-cultural violence.
\end{abstract}

Keywords: peace education, peace, violence, pictorial expression

\section{Introduction}

With the increase in religion-, ethnic origin-, politically or economically based social problems in national and international levels, in internal conflicts and in forced migrations, the notions of "peace" and "violence" that draw attention in historical contexts are now concentrated upon more. It is being emphasized that it is necessary to establish a social structure that is based on freedom, justice, democracy and toleration (UNESCO, 2005; Demir, 2011) and this process is supported by peace education programs. These changes and the peace education programs initiated contribute to the development of societies however they do not provide a reduction in violence as expected and cause the universal peace not to be sufficiently evident in the implementation level. For example, the attacks in Ankara on October 10, 2015 and in Paris on November 13, 2015 show that peace has not been truly established in the universal level and that violence can unsettle social peace anytime. Beside these incidents, in Turkey, the social problems on-going in Southeast and East Anatolian regions, ethnic conflicts throughout the country, the projection of the war going on in the country's border Syria on the world and especially on Turkey intensify the necessity to reconsider the way the notions "peace" and "violence" are perceived and the level of the relationship between each two notions.

The notion of peace is defined for the first time by Hugo Grotius in 1625 (Dobrosielski, 1987) as the end of war or direct violence (Castro \& Galace, 2010). This definition which can be called as negative peace means only that violence or war ends. Galtung (1969) defines the notion of peace in two dimensions, positive and negative. Negative peace is similar to Grotius' definition and is the absence or ceasing of direct violence. Positive peace represents a social justice environment where there is no structural (social), ecological and direct violence, which means negativities or where these negativities can be settled (Sağkal, Türnüklü, \& Totan, 2012). In this context, peace does not refer to a prevention of violence only, but also to individual, interpersonal and social respect, forgiveness, collaboration, tolerance against diversity, fairness and equity.

The notion of violence within the notion of peace is defined differently in literature, but it can generally be expressed as physical or nonphysical, individual or social negative behaviors. Direct violence is composed of 
phenomena such as child and woman abuse and war; social violence is composed of actions that can be seen throughout the society such as social pressure and hunger; sociocultural violence is composed of actions such as racism and religious pressure; and ecological violence is composed of environmental factors that adversely affects human life such as environmental pollution (Castro \& Galace, 2010). In this context, it can be stated that violence, similar to peace, has a multidimensional structure.

Peace education is based on the notion of peace and, included within this notion as a complement, the notion of violence. These two notions are adopted as the two building blocks of peace education. In basic education in Turkey, peace education or more precisely competences that are expected to be gained as a result of the application of peace education programs are emphasized partially or indirectly in Turkish, Life Sciences, Social Sciences and Religious Culture and Moral Knowledge courses, however according to Doğan and Kılınç (2014), peace education is not given sufficient place within the contents of these courses.

Peace education is defined in different ways in literature. Castro and Galace (2010) define peace education as an education that supports and transforms to a peace culture. Peace education has an important place for providing the knowledge, skills and attitudes to individuals that can be utilized in preventing the violence that is or will be present in individual or social context and in settling conflicts. There is scope for raising individuals that are away from violence, fair, and strongly sensitive to environmental and social issues and for ensuring social transformation as the power to maintain this in a systematic way. Haris and Morrison (2003) explain peace education with a philosophical approach and express it as a process that involves the acquisition of skills such as listening, reflecting, problem-solving, collaboration and dispute-settlement. It is possible to acquire peaceful attitudes and behaviors that will contribute to ending violence before it becomes a conflict, to possess a global citizenship consciousness as part of the sociocultural life, to develop the competence of reflective and participative thinking and further to these, to establish a sustainable peace environment (Brantmeier, 2007, 2013; Harris, 2004; Readrson, 2000; Fountain, 1999). For all these to occur in reality, it is crucial to spread peace education throughout schools and include it in instruction programs. Replacing war with peace requires the notion of peace to have a place in every grade of education starting with preschool education and to become a part of life.

Students reflect their acquisition related to peace education provided to them in school programs to their daily lives in various ways. These reflections take various shapes depending on the age level of school-age children. Pictorial representations are considered as one of these reflections. Drawings provide an insight to children's inner worlds and make it possible to discuss their world of emotion and though from a broader perspective. Children's drawings serve as a window to their emotions and thoughts and they can freely reflect their dreams onto paper (Crook, 1985). The emotions of children toward people or objects can again be understood through drawings (Burkitt, 2004).

The process of drawing requires the child to select and arrange colors, shapes and lines through synthesizing several components such as content, style, format and composition in order to convey an emotion, a thought, an event or an observation (Malchiodi, 2005). Children hate to answer the questions they are asked directly. Children express their feelings through lines with greater ease, fun and speed (Lewis and Greene, 1983). For this reason, as drawings are considered as an indicator of how the child perceives external world, they help adults in communicating with the child and overcoming the difficulties that the child faces (Artut, 2002). Drawing can also enhance children's critical thinking and understanding abilities and provide students the opportunity to develop the necessary skills to interpret images and include them in individual discourse (Uysal, 2011). A method to better understand what the pictorial expressions of children mean is to listen to what they say about their drawings (Malchiodi, 2005). The reason is that children tend to draw "what they know" rather than "what they see" in their drawings (Toomela, 2006). Moreover, children may draw what they see even in early ages and attribute special meaning to these (Cox, 1992; Cox, 1993). In this context, the best way to understand the message in children's drawings is to talk to them about their drawings or images.

When the researches conducted are analyzed, it is seen that the researches where the notions of peace and violence are considered together are limited. It is observed that there are studies such as perceiving violence in child drawings (Yurtal \& Artut, 2008; Farver \& Garcia, 2015; Kandıra \& diğerleri, 2012), emotional reflections of war (Jolley \& Vulic-Prtoric, 2001), the notion of peace in drawings and comics (Köse \& Bayır, 2014; Bulut \& Sarı, 2015; Naci, 2015), drawing peace and war (Aktaş, 2015; Walker, Myers-Bowman, \& Myers-Walls, 2003). The opposite of peace is always considered war. However the notion of direct violence is not much considered as the opposite of the notion of peace. In this study, the notions of peace and violence that form the basis for peace education are taken into consideration together and it is intended to provide a field for peace education.

In order to ensure social change and peace culture in societies, it is necessary to develop appropriate education 
programs that, in subjective basis, can meet the needs of the society in which the program will be implemented and then in later stages, contribute to the creation of a peace culture in universal level. For the development of programs needed be possible, it is required to study the perception and formation of the notions of "peace" and "war" in societies. Those listed above form the fundamental objective of this research. Subject to this fundamental objective, it was sought to find out how children perceive the notions of "peace" and "war" in their pictorial drawings and written and verbal expressions and the meanings that they attribute to each of these notions.

\section{Method}

\subsection{Research Design}

The research is conducted using phenomenological design. In phenomenological pattern, it is sought to understand the perceptions or experiences of participants in relation to a phenomenon through their own explanations (Patton, 2002; Yıldırım \& Şimşek, 2005; Creswell, 2009). In analyzing child drawings with phenomenological pattern, it is emphasized to be open to various meanings, contexts formed by meanings and the world-view of the drawer (Malchiodi, 2005). In the research, the perception of students on peace and violence and students' drawings on peace and violence are studied in relation to their views on these drawings.

\subsection{Application and Data Collection}

Research data are collected through student drawings and interview with students on their drawings. Research data are collected in Toplukonut Primary School, Yenişehir, Diyarbakır. The research involves 68 students. 37 of these students study in 5th grade and 31 study in 4th grade. The application of the research is carried out by the researcher. The researcher contacted related administrators and teachers in the school and obtained the necessary permission. Then, the researcher visited the classrooms, distributed drawing paper to students and asked the students to take out their colors and lead pencils. The students were asked to divide the drawing paper in two in the middle and draw what they understand when they hear the word "peace" on one side and the word "war" on the other side. The application lasted approximately one course hour that is 40 minutes.

After drawings were completed, the students were interviewed again in consequence of the analyses by the researcher and asked the question "what did you want to tell in this drawing of yours". The students were then asked to write answers that they give to the questions on the paper of their drawing with their own handwriting. The writings of the students were analyzed and interpreted by the researcher. Then, again on the basis of pictorial or written expressions, 14 students were interviewed face to face to avoid misinterpretation in some pictorial or written expressions. Students' families were asked for permission for these interviews. These interviews lasted approximately 3 to 5 minutes. All the interviews were recorded on a sound recorder.

\subsection{Data Collection Atmosphere}

Data collection of the research was conducted in the classroom of the students during Painting class in Toplukonut primary and secondary schools in Yenişehir Merkez in Diyarbakır. The classroom where the application was conducted had desks in three columns. When entering the room, there is a column of desks beside the wall and seven rows aligned back to back and right next to them, a second column aligned similarly and another column of desks beside the windows. The students were seated so that two students sit on one desk. The desks were organized independently for each student and possess the features that can meet individual requirements. Each classroom contains twenty one desks at total. These desks are comfortable enough for each two student groups. During the application, drawing papers were provided to the students by the researcher and lead and colored pencils were brought by the students themselves. The students were given one course hour (40 minutes) for the application and the application was conducted under the supervision of the researcher and painting teacher.

\subsection{Data Analysis}

From the data obtained from pictorial representations and written and verbal expressions of students, the pictorial representations and written expressions were analyzed through document analysis, and verbal explanations were analyzed through descriptive analysis method. In the data analysis stage, students' drawings and answers to the written and verbal questions were analyzed by the researcher and presented to domain experts in relation to which themes can be labeled as peace subtheme and which ones can be labeled as war subtheme. As a result of the analyses carried out, the themes that appear in students' pictorial representations and written and verbal expressions based on their pictorial representations were identified. The identification of these themes was based on the dimensions of the notions of peace and war identified by Castro and Galace (2010). Regarding the element of peace, 4 main themes were identified consisting of "Universal/intersocietal peace, intergroup/social peace, interpersonal peace and individual peace". Twenty five subthemes were formed under these 4 main themes. Regarding the element of violence, 4 main themes appeared consisting of "sociocultural violence, direct violence, 
intergroup violence and ecological violence". Under these 4 main themes, sixteen subthemes were created.

As a result of the analyses by experts, the items on which there is agreement and disagreement were identified. The reliability between researchers and domain experts was calculated using the formula Reliability=Agreement/ (Agreement+Disagreement) X 100 by Miles and Huberman (1994). The reliability value obtained is $97.2 \%$. According to Miles Huberman (1994), if 70\% or higher agreement of researcher and expert opinions is achieved in qualitative researcher, the study is considered reliable. Therefore, it can be said that this study is reliable. The drawings and written expressions that did not include the elements of peace and violence were removed in consultation with the experts.

In the interviews with the students, the students were asked whether they prefer to be addressed with their code names or real names and the students preferred to be called by their real names. For this reason, the real names of the students are used in the research and the students are directly quoted.

\section{Findings}

The findings obtained from students' pictorial, written and verbal expressions are provided under the themes of peace and violence. The findings were provided based on the pictorial expressions of the students and supported with their written and verbal expressions. The peace and violence definition by Castro and Galace (2010) was considered in the determination of main themes and the findings were presented based on this definition.

\subsection{Students' Opinions with regard to the Notion of Peace}

Students' pictorial, written and verbal expressions are gathered under four main themes and twenty five subthemes with respect to the notion of peace. These are given in Figure 1.

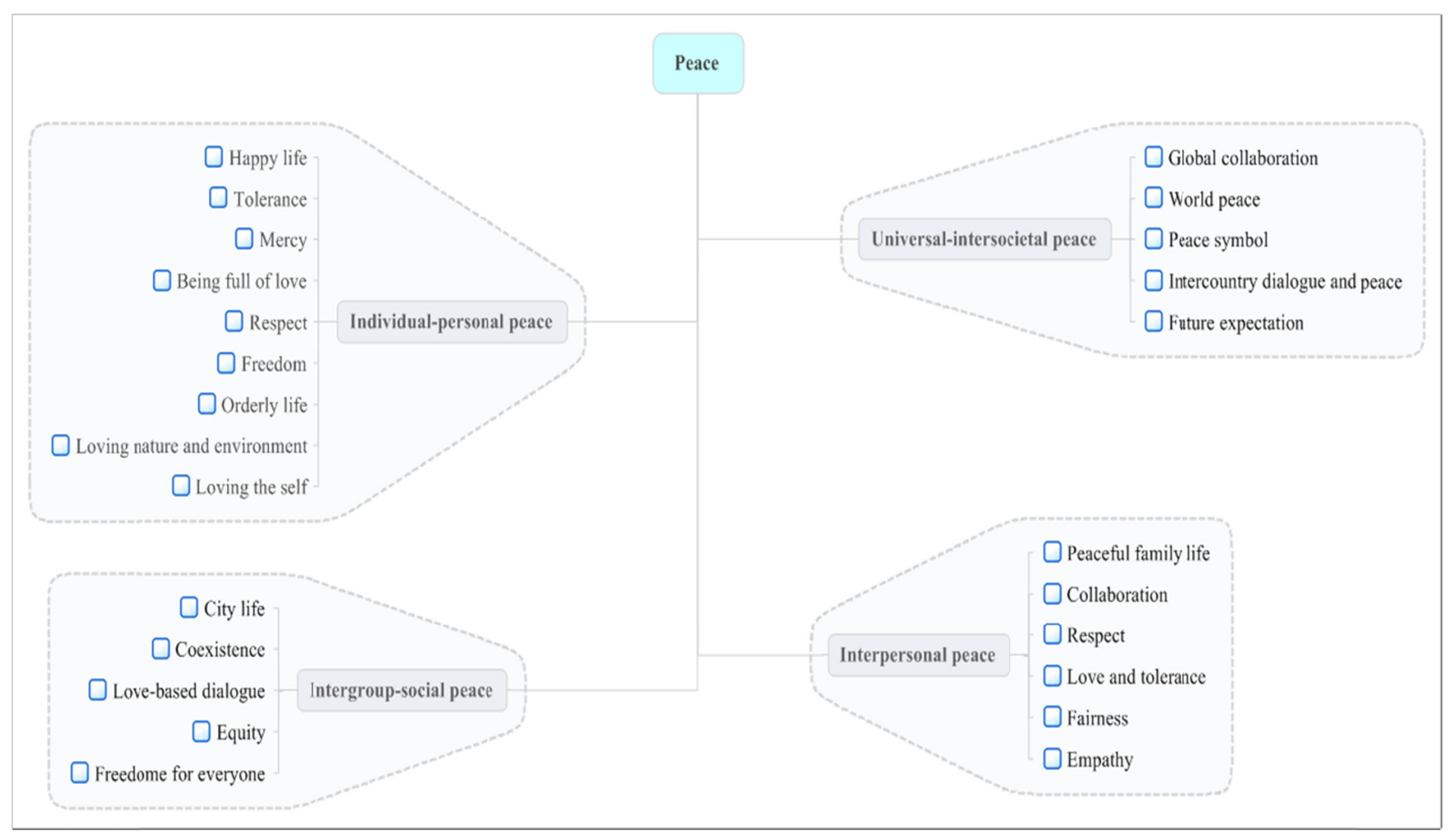

Figure 1. Themes pertaining to the notion of peace

Examining Figure 1, it is seen that there are four main themes, "universal/intersocietal peace", "intergroup/social peace", "interpersonal peace" and "individual peace". Individual peace consists of nine subthemes, interpersonal peace consists of six subthemes, universal/intersocietal peace and intergroup/social peace consist of five subthemes.

When students' drawings and written and verbal opinions are observed, it is seen that individual peace is predominant. It is followed by interpersonal peace, universal/intersocietal peace and intergroup/social peace, respectively. When students drew about peace, they gave prominence to individual peace. It can be said that they perceive peace in individual sense and interpret it that way. For example in Drawing 1, mutual love, respect and 
tolerance is depicted. Love especially outweighs and it is not a one-sided love, it is mutual and sincere. Deniz who drew Drawing 1 wrote on the back side of his drawing "I told in my peace drawing that we should join our hands and love each other as we love our brothers and sisters". Ezgi who has a similar opinion used the words under her drawing "In my peace drawing, two little girls share their presents with each other. The purpose here is love, respect, tolerance and peace. It means that peace is increased by two girls sharing their belongings."

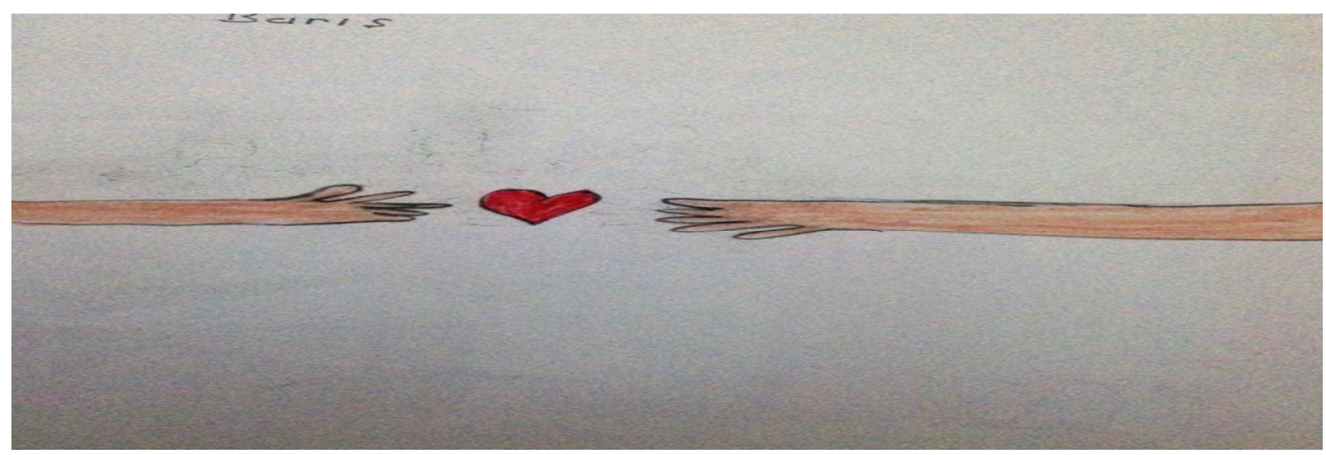

Drawing 1. Individual peace

In Drawing 2, freedom was emphasized. The drawer Cengiz can be said to see peace as individual because he explained his perspective about the drawing as "some children are not free when they are young. But those who grow old are always free, we also want to be free when we grow old". When Nazdar was asked how she defines peace, she used the words "I say peace is a world where there is no evil, there is love and people love each other".

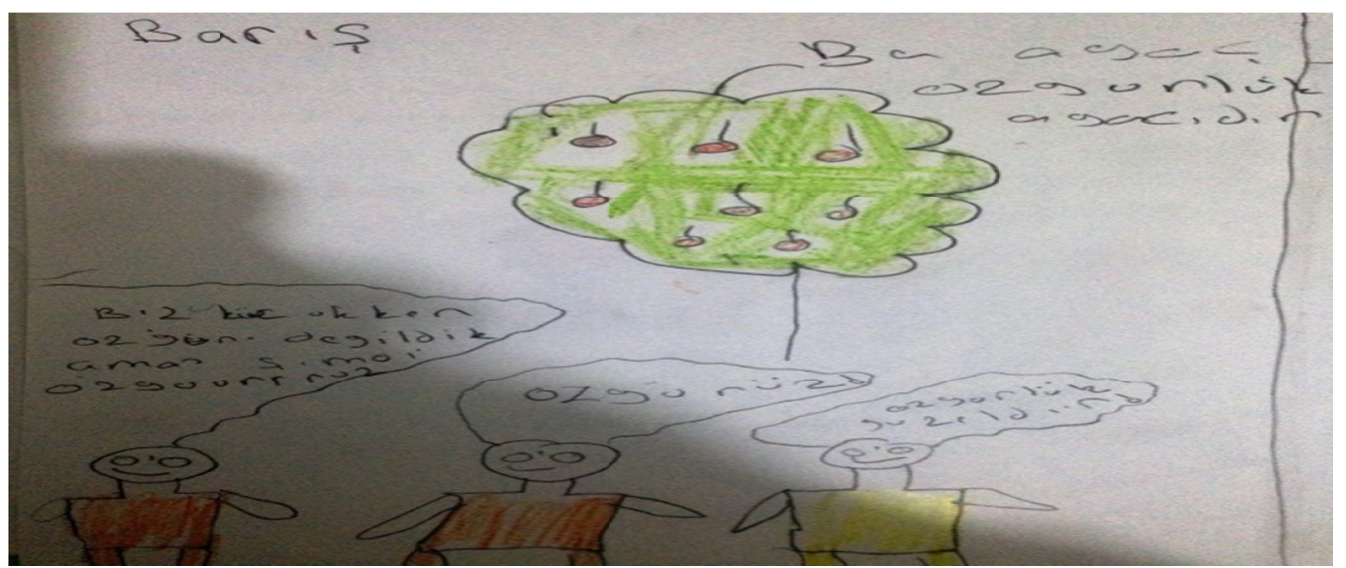

Drawing 2. Individual peace

Drawings 3 and 4 emphasize the universal dimension of peace. Particularly, many students used the symbol figure where all children in the world join hands in their own drawings. Elif who dress drawing 3 explained why she drew that as "I drew this picture because I see peace as world peace". Similarly, Emre who drew peace in Drawing 4 wrote "In my peace drawing, I told about a world where there is no evil and people are happy". Sarya who again drew the peace symbol as the main theme described her drawing with the words "I drew two happy girls in my peace drawing. And above them, I drew a slogan, we want peace, the symbol of world peace and a flying plane because for me, the greatest indicator of peace is happiness". In the interviews with students, they emphasized the universal dimension of peace with Mert defining peace as "there is a place for everyone in the world and countries should live in peace", Eylül as "why do countries make war anyway? How nice it would be if we could live together and make peace" and Sila as "everybody gathering under peace and live happily all the time". 


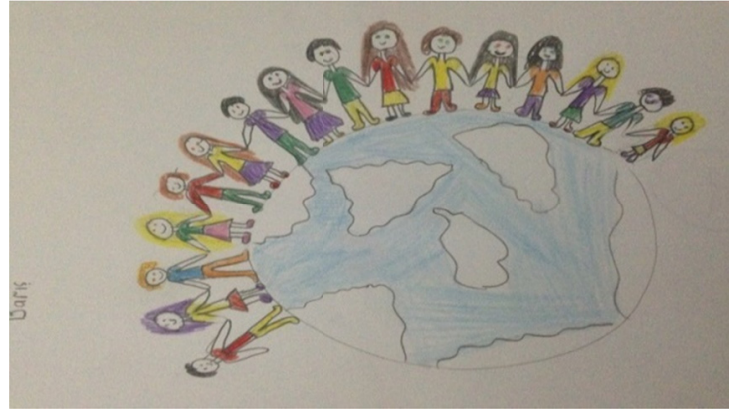

Drawing 3. Universal/intersocietal peace

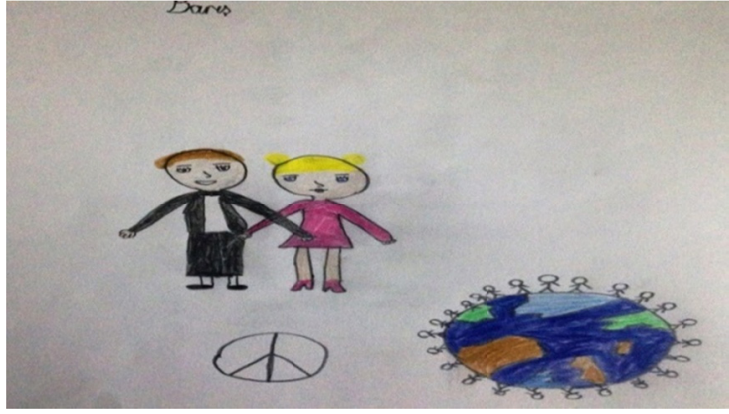

Drawing 4. Universal/intersocietal peace

It is seen that students highlight intergroup peace with Drawing 5. It is observed that students, in this context, often drew girl-boy figure joining hands and do not discriminate between those. In other words, from the perspective of children, there is not an ethnic, gender, religious or any kind of discrimination among groups. Nehir who drew Drawing 5 expressed her written opinion as "In my drawing named peace, I told that children are sisters and brothers and peaceful. To emphasize that children are sisters and brothers, I put the slogan "we all should be in peace". A similar opinion was given by a student named Vesile. Vesile drew a girl and a boy, joined their hands and wrote under the drawing "I drew a happy life of a happy boy and girl about peace". In Drawing 6, Cemre drew three different girls. It is seen in the drawing that all three girls are dressed differently and join hands. When Cemre was asked the reason, she provided her opinions as "I think that everybody is different. But it is not very important, we can be different but we should be friends and hold each other's hands. I thought so". Zilan who drew a similar drawing explained her opinion as "I drew this drawing to tell about friendship and kindness".

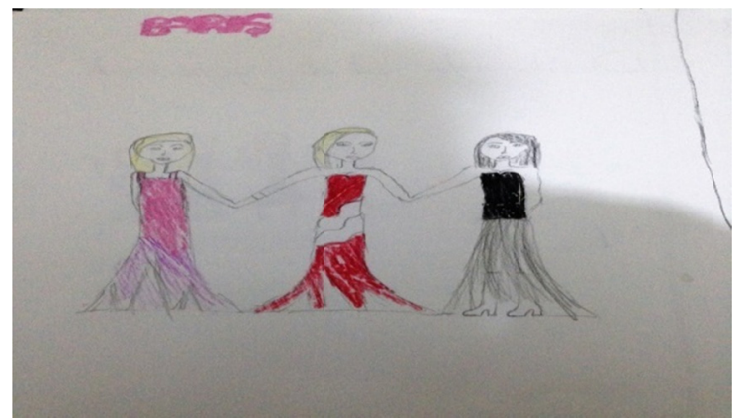

Drawing 5. Intergroup/Social peace

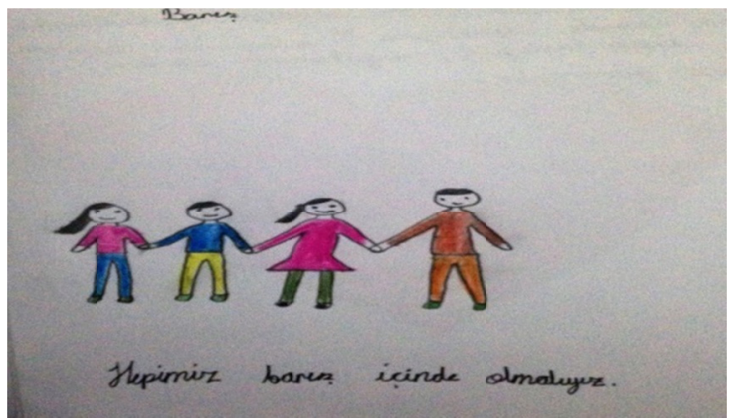

Drawing 6. Intergroup/Social peace

Drawings are considered as the images through which individual feelings can be expressed most easily from the perspective of children. In Drawing 7, it can be said that Furkan, with two happy boy figures in a heart, tries to express that people can be happy with love and tolerance. Furken noted under his drawing "I want all people; I mean kindness and evil to get together with love and respect. I want people to be tolerant to each other". In Drawing 8, peace is defined as a happy family. In this family of mother, father and child, mutual love, help and respect are addressed. Rasin who drew this used the words "I drew a happy family here. Everybody is full of love and happy". Among the students interviewed, Selin stated that "We should always live happily. We should not hurt anybody. We should listen to each other" while Sila emphasized empathy and fairness through her words "Now we are playing a game. If we are not fair in this game, we are unfair to our friend and also cause her to be sad. If someone else does this to us, I do not think we would like it”. 


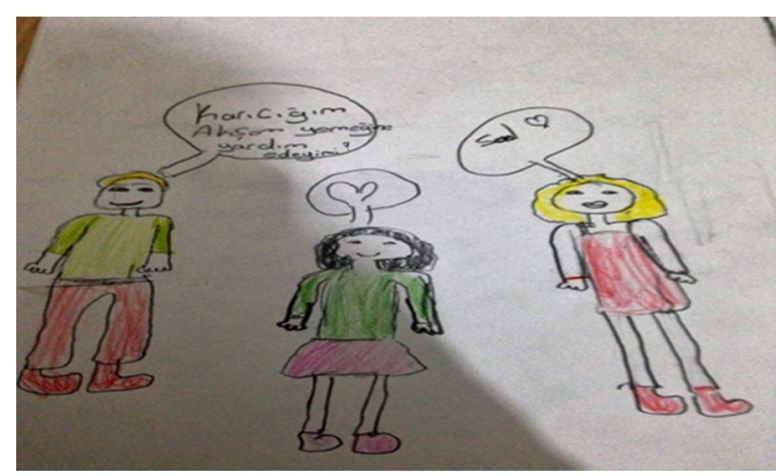

Drawing 7. Interpersonal peace

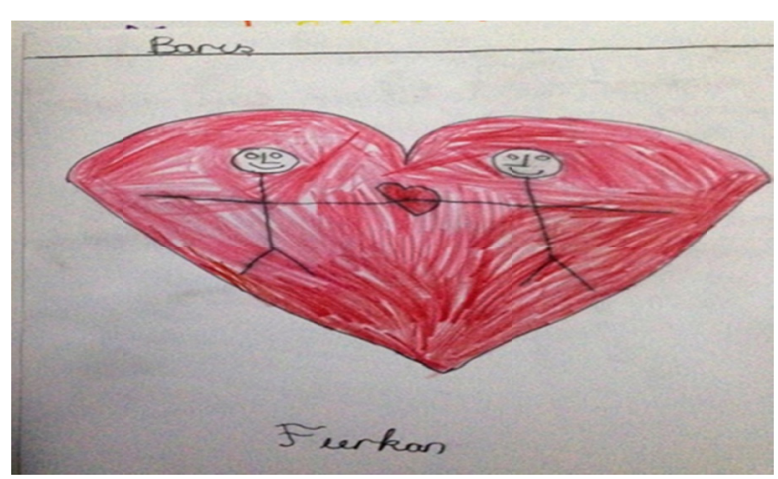

Drawing 8. Interpersonal peace

\subsection{Students' Opinions of the Notion of Violence}

In students' pictorial, written and verbal expressions, the notion of violence is grouped under four main themes and sixteen subthemes under them. These are given in Figure 2.

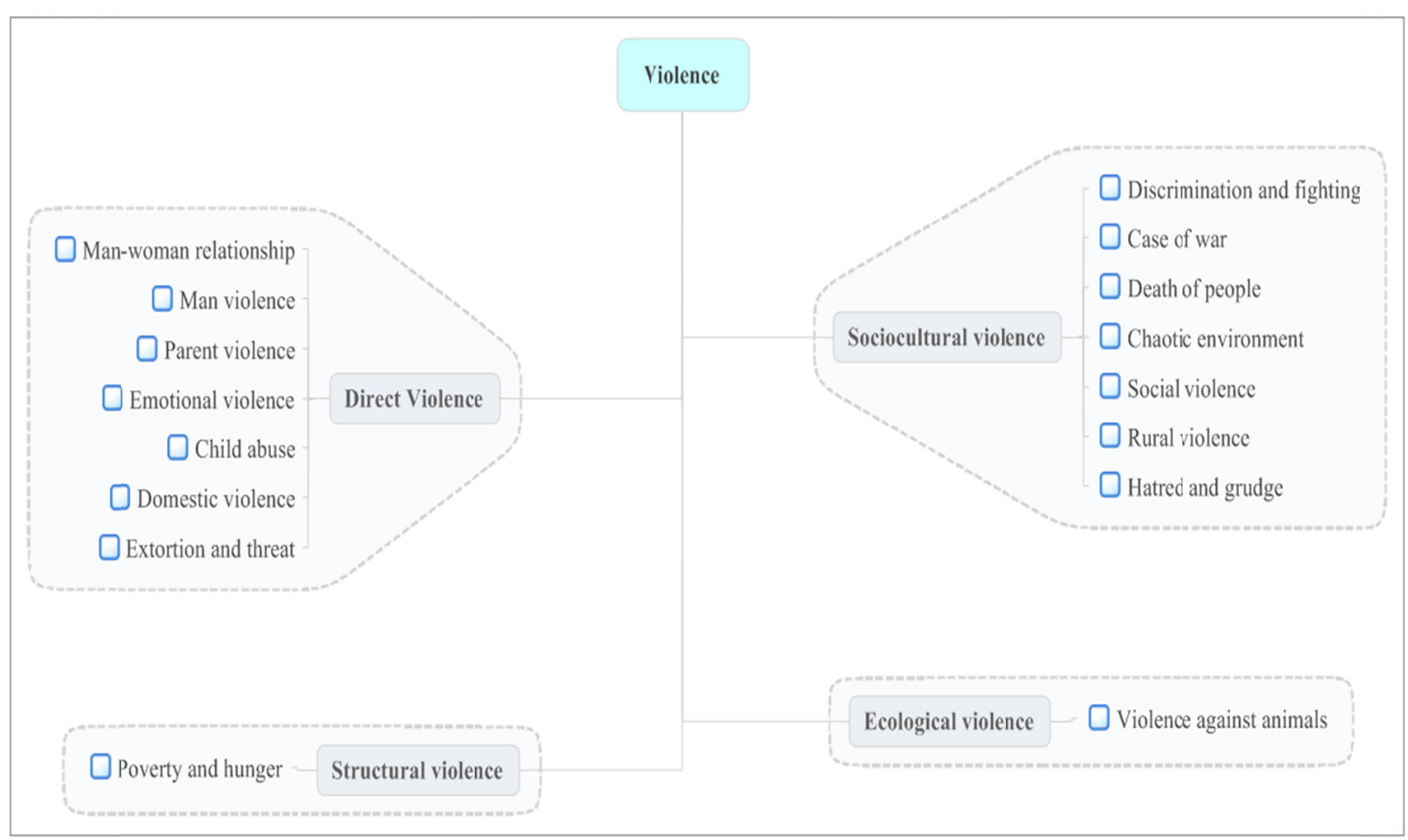

Figure 2. Themes pertaining to the notion of violence

Sociocultural violence and direct violence consist of seven subthemes and structural violence and ecological violence consist of one subtheme. When students' drawings and written and verbal opinions are observed, sociocultural violence and direct violence are seen to have a larger place in their daily lives. However, it was pointed out the structural violence and ecological violence is not observed much. In this context, students' pictorial, written and verbal opinions are provided below. It is seen that in their drawings the students drew direct violence elements in which physical violence is predominant. Drawing 9 and Drawing 10 can be shown as the two of the best examples to this. Dicle who drew Drawing 9 expressed her emphasis as "There is violence against women every day. I wanted to tell this in my drawing". Rasin who drew Drawing 10 drew a family in his picture and tried to depict the violence in a family. Rasin expresses direct violence with his note under his drawing. In the written text, Rasin said "I drew here a family that is destroyed because of the violence used by the man on the woman". In the interviews with students, they provided opinions that support the situation above. For example, Ayla stated the reflection of domestic violence on the child with words "When we get poor marks, our mother or 
father get mad at us at home. Mother and father of some beat them". Ayşe whose opinion was asked about violence explained violence as "women are always exposed to violence. And this violence is always used by men. End the violence against women". As can be seen, it can be said that students perceive and define violence as incidents with direct physical dimension and that are possible to occur.

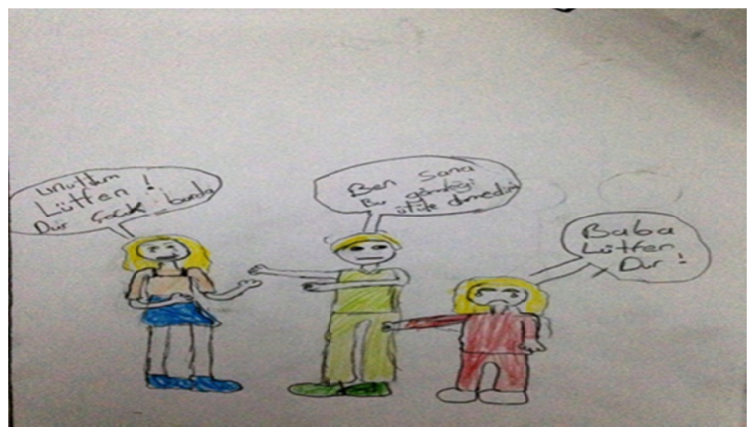

Drawing 9. Direct violence

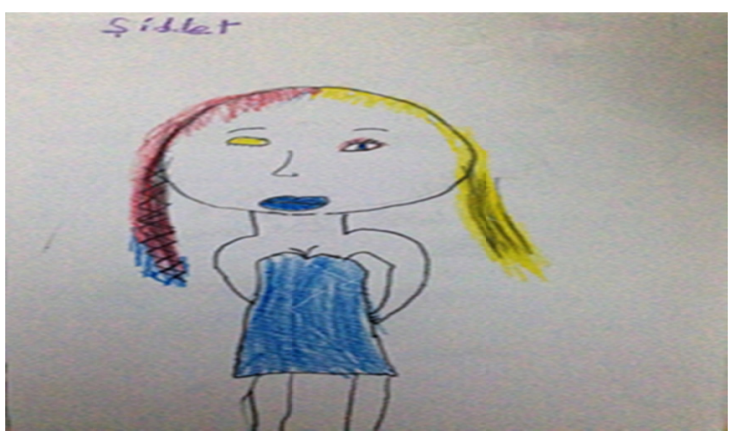

Drawing 10. Direct violence

Among the defined dimensions of violence, sociocultural violence appears as another dimension. Nurdan who drew Drawing 11 depicted violence as the tools that people use while committing violence and wrote this note on her drawing: "For me, violence is war. The things used in war are swords and guns after all. And this tells people of fear, confusion and sadness". Emre who drew Drawing 12 drew a boy who is excluded from a game played by two boys and give the reason for his exclusion as hatred. Emre stated in his written opinion "there is a boy who wants to play. But his friends do not accept him to the game because they hate him, they do not love him". In the interviews with children, Ayla emphasized social violence by describing violence as "In society, people get mad at each other very often. No one shows respect to no one. They always argue and they look at each other as if they are going to beat each other" and Efe emphasized rural violence with words "Violence is too much especially in villages. But nobody hears. People kill each other due to feud, not even police knows who committed the murder". It can be said that the students reflect on socio-cultural violence using the incidents that they actually experienced.

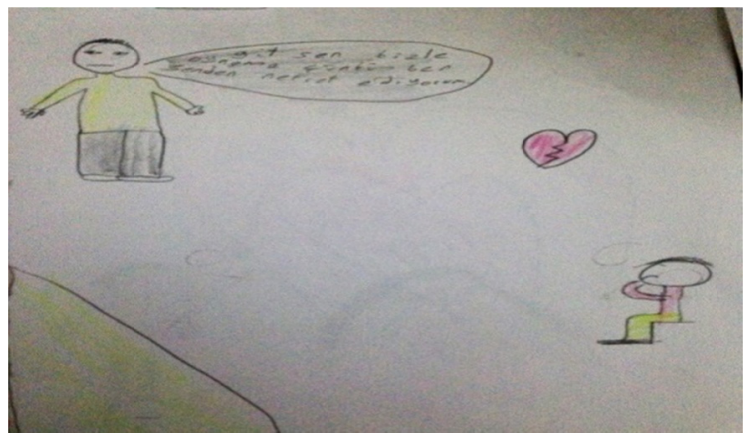

Drawing 11. Sociocultural violence

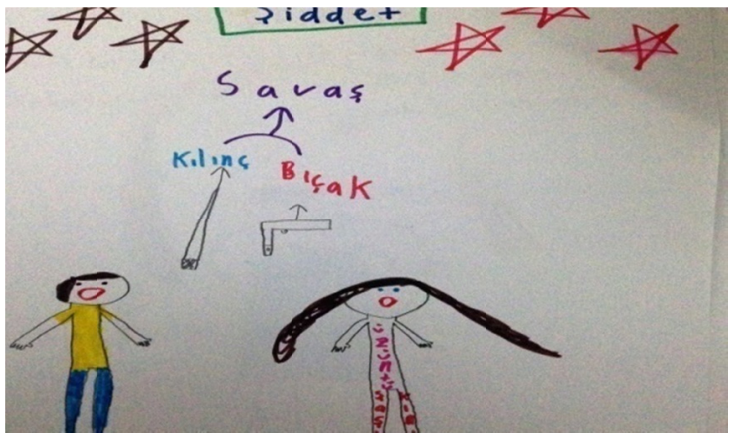

Drawing 12. Sociocultural violence

In the research, the structural and ecological dimension of violence is not given much place in students' pictorial representations, written statements and verbal opinions. However, Selim who drew Drawing 13 described his drawing as "Because people kill animals. I think nobody should intervene with animals". Sila who shared her written opinion that supports Selim wrote "In my drawing, I wanted to describe violence with a broken boat, a flower and a sad sun. Also there are no living things in my drawing because violence makes the person alone. No living things will stay around that person". Even though no drawings were drawn to describe structural violence, in the interviews conducted with children, Aliye explained her opinion as "every person has the right to live free, happy and with love and compassion. For this reason, some people may be poor. Since they are poor, they ask us for help. We do not help them and even yell at them or sometimes beat them. But it is not their fault to be poor or hungry". It can be said that the reason for children not to emphasize much on these two dimensions of violence is that they perceive violence as a direct physical violence. For this reason, it is seen that they do not have much knowledge about these two dimensions. 


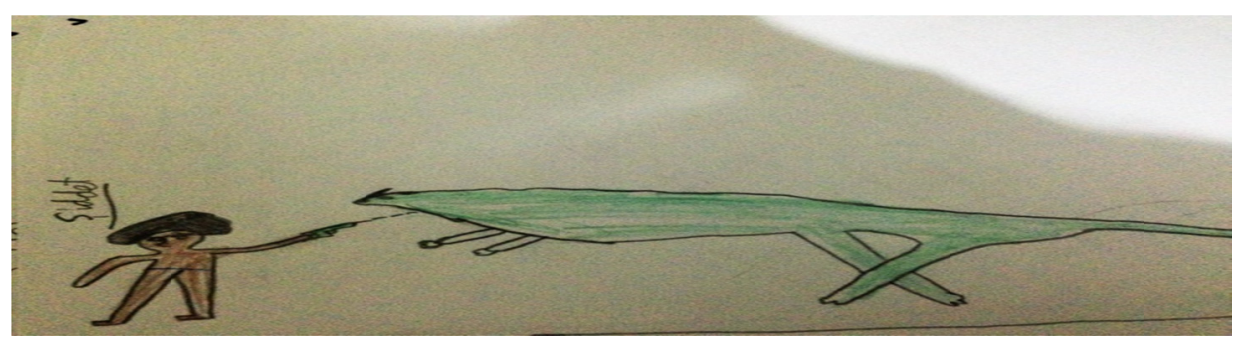

Drawing 13. Ecological violence

\section{Results and Discussion}

In this study, in which the concepts of "peace" and "violence" were tried to be determined in the pictorial drawings, literary and verbal expressions of elementary school students, four main themes were reached for both concepts. Each of these themes is subdivided into subcategories. Twenty-five sub-themes related to the concept of peace and sixteen sub-themes related to the concept of violence have been reached.

The most emphasized situation in the pictorial, literary and verbal expressions of the students related to the concept of peace has been reached as the result of personal peace. Universal/inter-societal peace, inter-group/societal peace and inter-personal peace followed this, respectively. Especially in children's drawings, the symbol of peace has come to the forefront under the theme of personal peace, and this symbol has been found to have an important place in children's world. In this, it is seen that children express themselves as ambassadors of peace over the symbol. For example, Ercan, who draws the symbol of peace, can be argued with his expression: "I see myself as a volunteer peace ambassador", which means that they actually know the meaning directly or indirectly implied by the symbol as content. As a matter of fact, Klein's and O'Neil's (2015) study showed similar results and it was seen that children painted the symbol of peace as a figure in their paintings.

It has been seen that the crises that have affected all over the world in recent years are reflected in the pictures of the students. In particular, forced migration and the living environment caused by the ongoing war and the conflict in Syria and Turkey in particular is reflected in the students' pictures. It is often reflected in the drawings of peace, in the eyes of children who have witnessed war and conflict, as a dream of living together in the world countries and with all the people. This imagery is common in the pictures of children, especially when they tell their future, and all people live together without discrimination of race, language, religion, color and sex. In fact, it can be said that there are not many thoughts about discrimination in children's world but these thoughts have developed over time. It can be argued that in the development of this situation, the phenomena and events that affect them in their daily lives and their surroundings have made an important contribution (Cox, 1993; E. Coates \& A. Coates, 2006; McLernon \& Cairns, 2001, 2006).

It has been observed that students are involved in concepts of love and freedom at a remarkable level in individual-personal peace, or in inter-group peace (Hakvoort \& Oppenheimer, 1998). While the students expressed that they wanted the concept of freedom for all people that they did not go for any separation they did not ignore the concept of equality. While describing the themes they have formed for the inter-group peace, it is seen that they use the male and female figurines together. While male and female figures emphasize coexistence, it can also be said that they also mean "living together" and "we can be different but we can live together". This is because it is revealed that children consider it with their both pictorial; and literary and verbal expressions.

It is every child's right to grow in a happy family and love environment. Children growing up in such an environment will be healthier, more peaceful, safer and happier. It has been seen that the students also express a happy and loving family environment in their pictorial, literary and verbal expressions. It can be said that there is no clue of the family environment in which the students live in their drawings, but there is such an expectation in the inner world of the students.

The concept of violence in the pictorial, literary and verbal expressions of the students shows itself more directly as violence and socio-cultural violence. Structural violence and ecological violence remain limited. This can be said that students' not perceiving ecological violence as a type of violence is the only reason behind this. A similar situation can also be argued in structural violence. Students see violence as physical and emotional violence when applied directly to them. It can be said that they perceive violence in a limited way and do not see it as violence in different dimensions.

When students evaluate violence directly in the context of violence, it appears that they strongly emphasize 
violence against women. Attitudes and behaviors based on direct physical violence by a man, usually based on male domination, have an important place in the paintings. In addition to this, violence in the relations between men and women, and parental violence in the family, are other aspects of emphasized violence. Especially when domestic violence is expressed by students, it is seen that there are also perceptions about male domination. The father applies violence to the mother at home, and if his expectations are not met, he solves it directly through violence. In many cases, such as lack of food at home, untidiness of the home, child's mischief, women are exposed to violence and students clearly express this in their pictorial, literary and verbal expressions. Not so frequently, however, they have described emotional violence, extortion and threats as well as child abuse as violence. They see emotional violence as a pressure from their peers. Students who say that they meet with situations such as theft and extortion, which are very rare by their peers, also regard this as violence. Because they do not accept that peers get what they have except their will. Students who see child abuse as violence do not accept and oppose the children being begged by their parents or elders especially on the streets (Yurtal \& Artut, 2008; Akbulut \& Saban, 2015).

The crisis in Syria is affecting many countries of the world. One of the most influenced countries by this crisis is Turkey. Despite the fact that the lives-on streets or caps- of people who migrated from Syria did not directly reflect on the pictures drawn by children, it is supported by the themes of war and chaotic environment. Socio-culturally violence of the war, the destruction of the social order, the loss of much of what people have, the complete deterioration of the traditions they are supposed to have, and the existence of uncertainties about their future are described as chaotic environments. The students have no expectations for the future in this context. Again, It is thought that if the people in a society do not understand each other -in their pictorial, literary, and verbal expressions- the violence is going to dissipate socially; that is, it will cause both discrimination and result in people's death. Another interesting result is that violence in city centers will be punished within the rules of law, but the perception that it is not possible in rural areas has emerged in the students. This can be explained by the fact that traditional relationships are more common in rural areas and problems are solved by these traditional understandings. Discrimination is considered another dimension of socio-cultural violence. In multicultural structures like Turkey, this carries a risk of conflict and violence. Students are emphasizing discrimination in their pictorial expressions, but they do not see it as religious, ethnic, gender-based and it can be said that they do, generally, not perceive discrimination.

Students' perceptions of peace and violence differ in their pictures, literary and verbal expressions. In the pictures of the students, peace is revealed as an imaginary image. Because when students draw peace, they have created and imagined an imaginary concept of peace in their minds. Very few illustrations show real life images. However, when it comes to the concept of violence, they are more realistic, under the influence of their daily lives, and picturing what they have experienced and seen around. On the other hand, it can be said while designing peace as an image or a dream, they perceived violence more realistic and concrete. This situation can be considered to be valid both in verbal and literary expressions.

As a result, it is seen that education is the base for increasing the peace, in the pictorial, literary and verbal expressions of the students and reducing the violence. Particularly, it is considered that the teaching of peace training directly or indirectly within the curricula will increase their problem solving skills. It is thought that peace education will contribute to the education of individuals who would prefer to engage in dialogue in problem solving, develop empathy skills, and refuse all forms of violence.

\section{References}

Akbulut, M., \& Saban, A. (2015). İlköğretim birinci kademe öğrencilerinin şiddetle İlgili algılarının çizdikleri resimler aracilığıla incelenmesi. Turkish Journal of Education, 1(1), 21-37. https://doi.org/10.19128/turje.181040

Aktaş, Ö. (2015). War and Peace in Student Drawings. Turkish Studies, 10(7), 97-110. https://doi.org/10.7827/TurkishStudies.8188

Artut, K. (2002). Sanat Eğitimi kuramları ve Yöntemleri (2. Baskı). Ankara: Anı Yayıncılık.

Brantmeier, E. (2007). Everyday understandings of peace and non-peace: peacekeeping and peacebuilding at a US Midwestern high school. Journal of Peace Education, 4(2), 127-148. https://doi.org/10.1080/17400200701523520

Brantmeier, E. (2013). Toward a critical peace education for sustainability. Journal of Peace Education, 10(3), 242-258. https://doi.org/10.1080/17400201.2013.862920

Bukut, S., \& Sarı, H. (2015). lköğretim İkinci Kademe Öğrencilerinin Bakış Açısıyla Barış Kavramının Resimlerinde Incelenmesi. 4. Ulusal Sosyal Bilgiler Eğitimi Sempozyumu. Bolu, 23-25 Nisan, 2015. 
Burkitt, E. (2004). Drawing Conclusions from Children's Art. The Psychologist, 17(10), 566-569.

Castro, L., \& Galace, J. (2010). Peace Education: A pathway to a culture of peace (2nd ed.) Quezon City: Center for Peace Education.

Coates, E., \& Coates, A. (2006). Young children talking and drawing. International Journal of Early Years Education, 14(3), 221-241. https://doi.org/10.1080/09669760600879961

Cox, M. (1992). Children's drawings. London: Penguin Books.

Cox, M. V. (1993). Children's drawings of the human figure. Hove: Lawrence Erlbaum Associates.

Crook, C. (1985). Knowledge and appearance. In N. H. Freeman, \& M. Cox (Eds., pp. 248-265), Visual order: The nature and development of pictorial representation. London: Cambridge University Press.

Demir, S. (2011). Türkiye'de Barış Eğitimine Bakış: Tanımlar, Zorluklar, Öneriler: Nitel İnceleme. Kuram ve Uygulamada Eğitim Bilimleri, 11(4), 1739-1745.

Dobrosielski, M. (1987). On the preparation of societies of life in peace. Bulletin of peace proposals, 18(3), 240. https://doi.org/10.1177/096701068701800303

Doğan, A., \& Kılınç, M. (2014). İlkokul Düzeyindeki Farklı Ders Kitaplarında Barış Ve Savaş Kavramlarına Yer Veriliş Düzeyinin Karşılaştırmalı Olarak İncelenmesi. Akademik Sosyal Araştırmalar Dergisi, 2(1), 277-289. http://doi.org/10.16992/ASOS.84

Farokhi, M., \& Hashemi, M. (2011). The Analysis of Children's Drawings: Social, Emotional, Physical and Psychological Aspects. Procedia-Social and Behavioral Sciences, 30, 2219-2224. https://doi.org/10.1016/j.sbspro.2011.10.433

Farver, J. A. M., \& Garcia, C. (2015). Living With Community Violence: Children Draw Their Neighborhoods. Retrieved from http://www.usc.edu/dept/LAS/SC2/pdf/farver.pdf

Fountain, S. (1999). Peace Education in UNICEF. New York: Programe Division UNICEF.

Galtung, J. (1969) Violence peace and peace research. Journal of Peace Research, 6(3), 167-191. https://doi.org/10.1177/002234336900600301

Hakvoort, I. and Oppenheimer, L. (1998). Understanding peace and war: A review of developmental psychology research. Developmental Review, 18(3), 353-389. https://doi.org/10.1006/drev.1998.0471

Harris, I. (2007). Peace education theory. Journal of Peace Education, 1(1), 5-20. https://doi.org/10.1080/1740020032000178276

Harris, I., \& Morrison, M. (2003). Peace Education (2nd ed.). Jefferson, North Carolina: McFarland \& Co.

Jolley, R., P., \& Vulic-Prtoric, A. (2001). Croatian children's experience of war is not reflected in the size and placement of emotive topics in the drawings. British Journal of Clinical Psychology, 40, 107-110. https://doi.org/10.1348/014466501163526

Kandıra, A., Sahin, F. T., Gelsiliç, Y., \& Yazıcı, E. (2012). The Reflection of Violence Perception on Drawings at Preschool Period Children. International Journal of Early Childhood Education Research, 1(1), 37-47.

Klein, C. S., \& O’Neil, R. (2015). Painting for peace in ferguson: A coloring book. United States: Threehouse Puplishing Gourps.

Köse, Ç. T., \& Bayır, G., Ö. (2015). Beşinci Sinıf Öğrencilerinin Resimlerinde Barış Algısı. İstanbul, I. Eurasian Educational Congress, 24-26 April, 2014.

Lewis, D., \& Greene, J. (1983). Your Child's Drawings: Their Hidden Meanings. London: Hutchinson.

Malchiodi, C. A. (2005). Çocukların Resimlerini Anlamak. Yurtbay, T. (çev.), İstanbul: Epsilon Yayıncılık.

McLernon, F., \& Cairns, E. (2001). Impact of political violence on images of war and peace in the drawings of primary school children. Peace and Conflict: Journal of Peace Psychology, 7(1), 45. https://doi.org/10.1207/S15327949PAC0701_04

McLernon, F., \& Cairns, E. (2006). Children's attitudes to war and peace: When a peace agreement means war. International Journal of Behavioral Development, 30(3), 272-279. https://doi.org/10.1177/0165025406066763

Naci, S. (2015). lköğretim İkinci Kademe Öğrencilerinin Bakış Açıslyla Barış Kavramının Resimlerinde Incelenmesi. 4. Ulusal Sosyal Bilgiler Eğitimi Sempozyumu. Bolu, 23-25 Nisan, 2015. 
Reardon, B. A. (1988). Comprehensive peace education: Educating for global responsibility. New York: Teachers College Press.

Sağkal, A. S., Türnüklü, A., \& Totan, T. (2012). Kişilerarası Barış İçin Empati: Barış Eğitiminin Empati Becerilerine Etkileri. Kuram ve Uygulamada Ĕ̈itim Bilimleri, 12(2), 1447-1460.

Toomela, A. (2006). Generic represantations in children's drawings. TRAMES, 10(60-55), 4, 341-354

United Nations Educational, Scientific and Cultural Organization (UNESCO). (2005). Framework for teachers. India: New Delhi.

Uysal, A. (2011). Görsel Kültürün ve Sosyo-kültürel olguların öğrenci resimlerindeki imgelere etkileri. Akademik Bakı̧ Dergisi, 24.

Walker, K., Myers-Bowman, S. K., \& Myers-Walls, J., A. (2003). Understanding War, Visualizing Peace: Children Draw What They Know. Journal of the American Art Therapy Association, 20(4), 191-200. https://doi.org/10.1080/07421656.2003.10129605

Yurtal, F., \& Artut, K. (2008). The Reflections of Children's Perception of Violence on Their Drawings. Turkish Journal of Child and Adolescent Mental Health, 15(3), 149-155.

\section{Copyrights}

Copyright for this article is retained by the author(s), with first publication rights granted to the journal.

This is an open-access article distributed under the terms and conditions of the Creative Commons Attribution license (http://creativecommons.org/licenses/by/4.0/). 